Sains Malaysiana 50(8)(2021): 2407-2417

http://doi.org/10.17576/jsm-2021-5008-22

\title{
Non-Isocyanate Polyurethane (NIPU) Based on Rubber Seed Oil Synthesized via Low-Pressured Carbonization Reaction
}

\author{
(Poliuretana Bukan Isosianat (NIPU) Berasaskan Minyak Biji Getah yang Disintesis secara Tindak Balas \\ Karboksinasi Bertekanan-Rendah)
}

\section{R.A. RADEN Siti AMirah, M.A. FAIZA* \& A. Zuliahani}

\begin{abstract}
Epoxidised rubber seed oil (ERSO) was successfully synthesized into non-isocyanate polyurethane via carboxylation method whereas peroxoformic acid was formed by in-situ reaction for epoxidation. The effects of temperature and ratio of hydrogen peroxide and formic acid to rubber seed oil carboxylation were studied. The optimum temperature for the epoxidation reaction was found at $50{ }^{\circ} \mathrm{C}$ to avoid ring opening reaction of epoxy whilst the optimum ratio of hydrogen peroxide and formic acid is equal molar of double bond: formic acid at 1:2 and 1:1, respectively. At a lower concentration of hydrogen peroxide and formic acid, the oxirane ring was stable due to the lower hydrolysis (oxirane cleavage) of an epoxide. The effect of using low content of formic acid tends to minimize unwanted epoxide ring opening to occur and make the epoxidation rate increased with increasing of oxirane number. Fourier transform infrared (FTIR) spectral displayed the presence of an epoxy functional group at $822 \mathrm{~cm}^{-1}$ and the disappearance of double bond peak at $3011 \mathrm{~cm}^{-1}$ corresponding to epoxidised oil and carbonyl group confirmed the epoxidation reaction had taken place. ${ }^{1} H-N M R$ was used to confirm the formation of carboxylate functionality after the reaction of epoxy at $\delta 4.83$ and $4.61 \mathrm{ppm}$. In conclusion, ERSO has great potential to be used as a precursor in producing environmentally friendly non-isocyanate polyurethane.
\end{abstract}

Keywords: Carboxylated oil; epoxidised oil; non-isocyanate; polyurethane; rubberseed oil

\section{ABSTRAK}

Minyak biji getah terepoksi (ERSO) berjaya disintesis menjadi poliuretana bukan isosianat melalui kaedah karboksilasi sedangkan asid peroksoformik dibentuk oleh reaksi in-situ untuk epoksidasi. Kesan suhu dan nisbah hidrogen peroksida dan asid formik kepada karboksilasi minyak biji getah dikaji. Suhu optimum untuk tindak balas epoksidasi didapati pada suhu $50{ }^{\circ} \mathrm{C}$ untuk mengelakkan tindak balas pembukaan cincin epoksi sementara nisbah optimum hidrogen peroksida dan asid formik adalah molar ikatan berganda yang sama: asid formik masing-masing pada kadar 1: 2 dan 1: 1. Pada kepekatan hidrogen peroksida dan asid formik yang lebih rendah, cincin oksirana stabil kerana hidrolisis yang rendah (pembelahan oksirana) epoksida. Kesan penggunaan kandungan asid formik yang rendah cenderung untuk mengurangkan pembukaan cincin epoksida yang tidak diingini berlaku dan menjadikan kadar epoksidasi meningkat dengan bertambahnya bilangan oksirana. Spektrum inframerah transformasi Fourier (FTIR) memperlihatkan kehadiran kumpulan berfungsi epoksi pada jarak $822 \mathrm{~cm}^{-1}$ dan hilangnya puncak ikatan berganda pada $3011 \mathrm{~cm}^{-1}$ yang sepadan dengan minyak terepoksi dan kumpulan karbonil mengesahkan reaksi epoksidasi telah berlaku. ${ }^{1} H-N M R$ digunakan untuk mengesahkan pembentukan fungsi karboksilat setelah tindak balas epoksi pada $\delta$ 4.83 dan 4.61 ppm. Kesimpulannya, ERSO berpotensi besar untuk digunakan sebagai pendahulu dalam menghasilkan poliuretana bukan isosianat yang mesra alam.

Kata kunci: Bukan isosianat; minyak getah; minyak karboksilasi; minyak terepoksi; poliuretana 


\section{INTRODUCTION}

Polyurethane (PU) is a polymeric material that has versatile properties. It can be synthesized into different types such as rigid foam, flexible foam, integral form and elastomers depending on material and method used (Huang et al. 2015; Rosato 1993). Fully reacted PU should be chemically inert. However, it is still producing dust inducing mechanical irritation to the eyes and lungs. Unreinforced PU has a melting temperature in a range of $75-137{ }^{\circ} \mathrm{C}$ and it is a combustible material that easily explodes with long exposure to fire (Harper \& Petrie 2003). Generally, PU begins to degrade at approximately $240{ }^{\circ} \mathrm{C}$. During the combustion, PU containing unreacted isocyanate is decomposed to a variety of harmful products including isocyanates and other irritant agents such as carbon monoxide, nitrogen oxide, aldehydes and hydrogenated halocids (Boutin et al. 2004).

Hence, a new development in synthesizing nonisocyanate polyurethane (NIPU) had been studied as a concern towards human health. NIPU displays increased chemical resistance and lower permeability as well as improved water absorption and thermal stability (Karateev et al. 2014; Mohd Soberi et al. 2017). These properties making NIPU great potential in various applications such as chemical-resistant coating, sealant and foam. Limited researches have been conducted using non isocyanate precursors in NIPU production using soybean oil and cashew nut shell liquid (CNSL) (Datta \& Włoc 2016; Raden Siti Amirah et al. 2013). Natural oils or vegetable oils are lipid materials derived from plants and can be found abundantly and become a popular material to produce hydrocarbon chemicals as to replace petroleum. The usage of these natural resources reduces the dependency on petroleum material. Vegetable oils are composed of triglycerides, ester derived from glycerol and three fatty acids such as palmitic acid, oleic acid, and alpha-linolenic acid. There are many studies on the usage of vegetable oils such as soybean oil (Lu \& Larock 2010), castor oil (Corcuera et al. 2010) and linseed oil (Yadav et al. 2009) in industries such as converting it into biodiesel (Ikwuagwu et al. 2000). The researches on deriving NIPU from biomass vegetable oil especially from rubber seed still new since there is none research work being reported elsewhere. Rubber seed oil can be found abundantly since it is derived from plants.
In this study, NIPU was synthesized from rubber seed oil and has been published in our previous study via low pressure carbonization method (Raden Siti Amirah et al. 2013). The high oleic content of rubber seed oil which presenting the double bond in triglyceride contributes to the potential in chemical modification as a precursor in NIPUs. The activation of double bonds through epoxidation via low pressure carbonization is influenced by temperature and reactants due to the process of ring opening to form hydroxyl and dimer. The polyaddition of cyclic carbonates (CC) from ERSO with EDA is an alternative method in producing NIPUs for greener and sustainable technology. In this research, we reported the synthesis of ERSO at different reaction temperatures and ratios of formic acid and hydrogen peroxide via oxirane number, FTIR and ${ }^{~} \mathrm{HNMR}$ spectrals. Whilst the formation of NIPUs from CC and ethylenediamine (EDA) were characterized and reported using FTIR and ${ }^{1}$ HNMR.

\section{MATERIALS AND METHODS}

Rubber seed oil was obtained from Lembaga Getah Malaysia (LGM) having an iodine value of $180 \mathrm{~g} \mathrm{I}_{2} / 100 \mathrm{~g}$. Formic acid 98\%, diethyl ether, tetrabutyl ammonium bromide (TBABr) and ethylenediamine were purchased from Merck. Hydrogen peroxide 35\%, sodium carbonate, sodium sulphate, glacial acetic acid, potassium hydrogen phthalate was purchased from Systerm. All chemicals were used as per received.

\section{INSTRUMENTS}

Perkin-Elmer 2000 acquired a Fourier transform infrared (FTIR) transmittance spectrum of sample. Nuclear magnetic resonance (NMR) spectroscopy was performed on Perkin-Elmer run on $300 \mathrm{MHz}$ and samples were dissolved using deuterated Chloroform $\left(\mathrm{CDCl}_{3}\right)$.

\section{SYNTHESIS OF EPOXIDISED RUBBER SEED OIL (ERSO)}

Rubber seed oil (RSO) was placed in a reaction vessel and heated in a water bath while mechanically stirred at $50{ }^{\circ} \mathrm{C}$ and a speed of $500 \mathrm{rpm}$. A calculated amount of formic acid and hydrogen peroxide was added dropwise into the oil, at a rate such that the addition was completed within one hour. Aliquots of sample were withdrawn at various time intervals, by considering the addition of reactants 
as zero time. When the reaction had completed, the yield was extracted with diethyl ether, rinsed with distilled water thrice and mixed with sodium carbonate and sodium sulphate. Samples were analyzed for oxirane content and iodine value as well as FTIR and ${ }^{1} \mathrm{HNMR}$ spectroscopy to observe the conversion of a double bond to epoxy ring (ASTM D5554 - 95 2011; Durbetaki 1958).

\section{SYNTHESIS OF CYCLIC CARBONATE FROM EPOXIDISED RUBBER SEED OIL WITH LOW-PRESSURE METHOD}

Cyclic carbonate was synthesised from ERSO as reported in our previous studies (Raden Siti Amirah et al. 2013). Epoxidised rubber seed oil (ERSO) was placed in a flask and heated in an oil bath to $100{ }^{\circ} \mathrm{C}$ while being magnetically stirred at $500 \mathrm{rpm} .5 \mathrm{~mol} . \%$ of tetrabutyl ammonium bromide (TBABr) that acted as catalyst was added into ERSO and stirred for about $10 \mathrm{~min}$ as to dissolve it while mild pressure of carbon dioxide gas was introduced. Then, temperature and gas pressure were increased to $150{ }^{\circ} \mathrm{C}$ and 10 psi. While maintaining the temperature and pressure, aliquots of sample were taken at an interval time to observe the conversion of the epoxy ring into a cyclic carbonate group. The aliquots were analysed via oxygen oxirane content test as to monitor the conversion. After the reaction had been completed and reached the desired amount of yield conversion, the carbon dioxide gas supply was stopped. TBABr catalyst was removed by heating the yield (carboxylated oil) to $190{ }^{\circ} \mathrm{C}$ for $2 \frac{1}{2} \mathrm{~h}$ with constant stirring by taking advantage of Hofmann elimination reaction (Doll \& Erhan 2005a). The carboxylated oil sample was characterized via FTIR and ${ }^{1}$ HNMR spectroscopy to observe the conversion of the epoxy ring into carboxylate ring.

\section{PREPARATION OF NON-ISOCYANATE POLYURETHANE}

NIPU was prepared based on our previous study (Raden Siti Amirah et al. 2013). Carboxylated oil (CO) was placed in a beaker and heated to $60{ }^{\circ} \mathrm{C}$ while being stirred magnetically. Calculated ethylenediamine (EDA) was added and the mixture was continued being stirred for about $10 \mathrm{~min}$. The viscous mixture was then coated onto Teflon sheet and placed in an oven at 80 ${ }^{\circ} \mathrm{C}$ for $12 \mathrm{~h}$ to ensures complete curing occurred as to produce transparent and flexible polymeric material. The cured polyurethane sample was characterized via FTIR spectroscopy.

\section{RESULTS AND DISCUSSION}

\section{EFFECT OF TEMPERATURE}

RSO was synthesized with peroxoformic acid formed insitu. Throughout the reaction, epoxide concentration was observed using direct titration method with hydrobromic acid solution in acetic acid which resulting in oxygen oxirane content (OOC) number. Effect of temperature was observed with epoxidation reaction carried out in the molar ratio of 1:0.47:0.47 - double bonds: formic acid: hydrogen peroxide at three different temperatures $\left(50,60\right.$ and $\left.70{ }^{\circ} \mathrm{C}\right)$. Samples are designated as T50, T60, and T70. Figure 1 illustrated OOC number at the applied temperatures. Double bonds conversion was relatively fast at $\mathrm{T} 70$ where maximum epoxy number already achieved after $1.95 \mathrm{~h}$. Even though T70 displayed high conversion rate, epoxy number for $\mathrm{T} 70$ was the lowest amongst other two temperatures. This circumstance implied low temperature, $50{ }^{\circ} \mathrm{C}$ more suitable for epoxidation reaction compared to higher temperature. At higher temperature epoxy ring did not stable and ring opening tend to occur. This is in line with results from whereas the rate of ring opening increases with increased reaction temperature as the diffusive mobility of generated acid is increased and makes the rings of epoxide to open (Chiniwalla et al. 2003). Apart from that, according to Hong et al. (2015), an optimum level of epoxidation could be obtained at reaction temperature that range of $45^{\circ} \mathrm{C}$ at which epoxide degradation would be minimal. Although the epoxidation rate is lowered at low reaction temperature, it gave more stable oxirane rings. Moreover, higher operating temperature are not preferred as the addition of hydrogen peroxide which is exothermic reaction would lead to explosion.

\section{EFFECT OF HYDROGEN PEROXIDE AND FORMIC ACID}

Figure 2 explained the effect of hydrogen peroxide on the oxirane number in epoxidation reaction. The epoxidation was conducted in constant molar ratio of 1:1 - double bond: formic acid while increased molar ratio of hydrogen peroxide - 1, 2 and 2.5. Samples were assigned as HP1, HP2, HP2.5, respectively, following increased in molar 


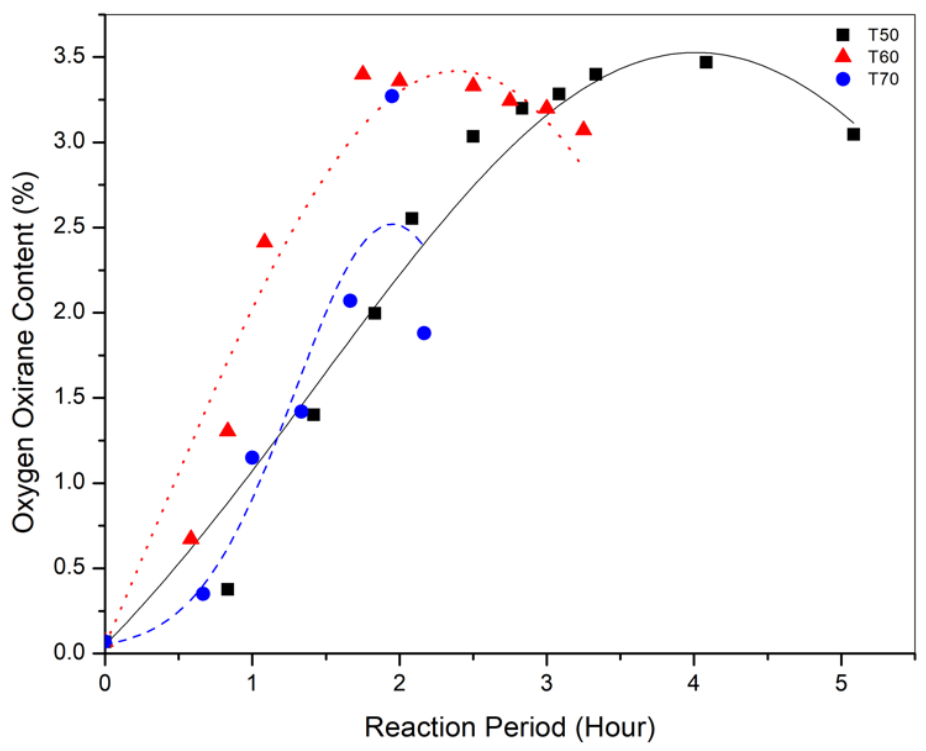

FIGURE 1. Oxygen oxirane content vs reaction period at different temperature for epoxidation of RSO

ratio. From Figure 2, HP2.5 signified in optimum oxirane number compared to HP1 and HP2. This concluded that increasing molar ratio of hydrogen peroxide, resulting in increasing of oxirane number. This is supported by research conducted by Abdullah and Salimon (2010), where using higher content of hydrogen peroxide is significantly detrimental for achieving high oxirane number. The higher concentration of acid could reduce the reaction time and resulted in higher oxirane content with lesser cleavage. Additionally, rate of epoxidation can be approximately calculated from the trend line equation of Figure 2. Figure 4 indicated result from calculated epoxidation rate where maximum number epoxide group achieved. Nonetheless, HP1 exhibited lowest oxirane number, the epoxidation reaction rate relatively higher than HP2.5. The stability of oxirane ring was very poor at higher concentration of hydrogen peroxide, that leads to lower epoxidation rate (Hong et al. 2015).

Whereas Figure 3 represented the effect of increasing amount of formic acid while molar ratio of double bonds and hydrogen peroxide remain constant. Formic acid molar ratio was increased from 1 to 2 and

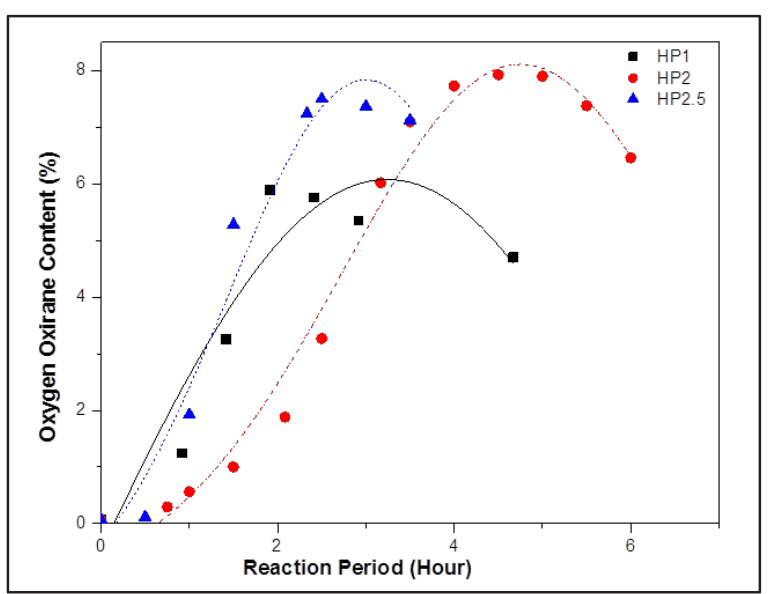

FIGURE 2. Oxygen oxirane content vs. reaction hour at different hydrogen peroxide molar ratio for epoxidation of RSO

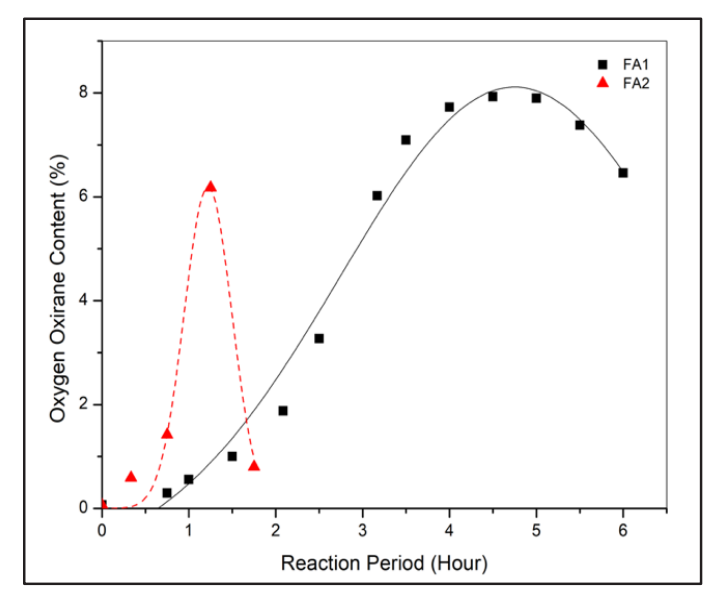

FIGURE 3. Oxygen oxirane content vs. reaction hour at different formic acid molar ratio for epoxidation of RSO 


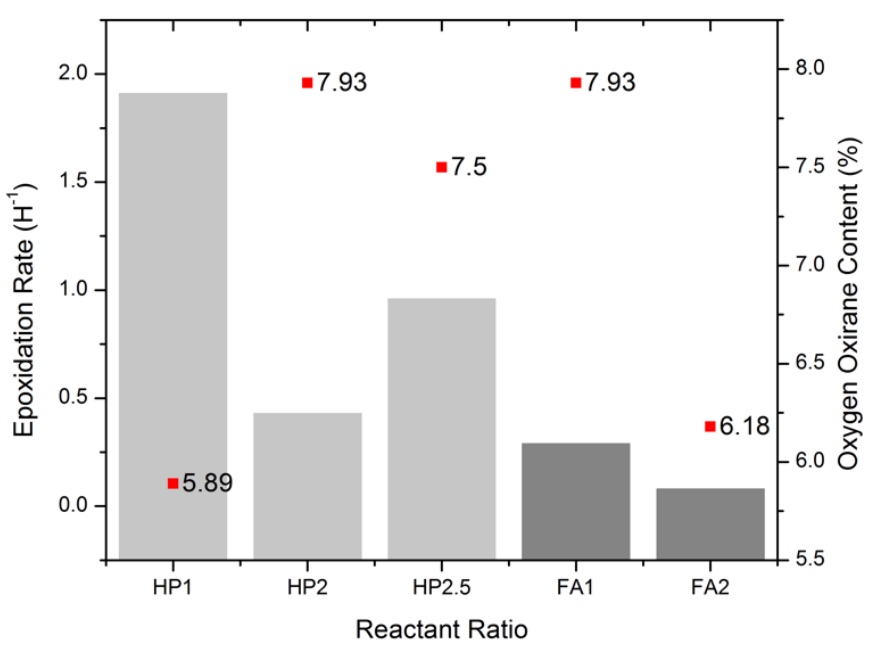

FIGURE 4. Epoxidation rate difference in hydrogen peroxide ratio and formic acid ratio

samples were designated as FA1 and FA2, respectively. Figure 3 concluded as increased amount of formic acid, epoxide number produced was reduced although maximum epoxide achieved at faster rate. According to Hong et al. (2015), the oxirane ring was not stable in higher formic acid content and tends to promote the hydrolysis (oxirane cleavage) of epoxide, hence, decreasing the final yield. The effect of using low content of formic acid tend to minimize unwanted epoxide ring opening to occur and make the epoxidation rate increased with increasing of oxirane number.

\section{EPOXIDATION REACTION MECHANISM}

Epoxidation is a process where an oxirane ring is formed with peroxyacid generated in situ. Figure 5(i) shows formic acid acted as an active oxygen carrier while hydrogen peroxide is an oxygen donor in forming peroxyacid. This generated peroxoformic acid then reacted with a triglyceride molecule in rubber seed oil as represents in Figure 5(ii). The extra oxygen (label in red) between oxygen and hydrogen bonding in the peroxoformic acid is very unstable, thus, very reactive.
Due to that, this oxygen that is closest to hydrogen will react with carbon-carbon double bond (label in green) and form one bond (label as 1). Then the double bond (label in green) breaks its pi bond and creates another bond with oxygen (label in red) and eventually forms a ring (label as 2). Consequently, the weak bond (label in pink) between two oxygen in peroxoformic acid breaks and the electron moves to the carbonyl carbon-oxygen bond (label in brown) and create a pi bond result in another carbonyl bond (label as 3). Now the carbon has too many bonds, it will break the pi bond of carbon-oxygen (label in brown) from initial carbonyl in peroxoformic acid (label as 4). This electron then moves out and reaches the hydrogen (label in blue) and forms a bond. Hydrogen, on the other hand can only form one bond. Thus, it releases its bond with the oxygen that already formed an epoxy ring (label as 5).

\section{CARBOXYLATION REACTION MECHANISM}

Carboxylation is a process to produce carboxylate ring which later converted into a urethane linkage. Carboxylation process starts with a ring opening of the 
epoxide. As illustrated in Figure 6(i), the epoxide ring opening is assisted with a catalyst, TBABr. The C-O-C bond angle of epoxide ring is supposed to be $109^{\circ}$ but it is being compressed like a spring to be $60^{\circ}$ angle. This makes the sharp C-O-C bond angles are more reactive than any typical acyclic ether and makes it an easy target for nucleophilic attack. The electronegativity of oxygen (label in brown) makes oxygen to be partially negative charge and carbon (label in red) to be partially positive charge. The bromine anion in TBABr will attack (label as 1) partially positive charge carbon (label in red). Result in carbon-oxygen bond (label in pink) to break (label as 2)

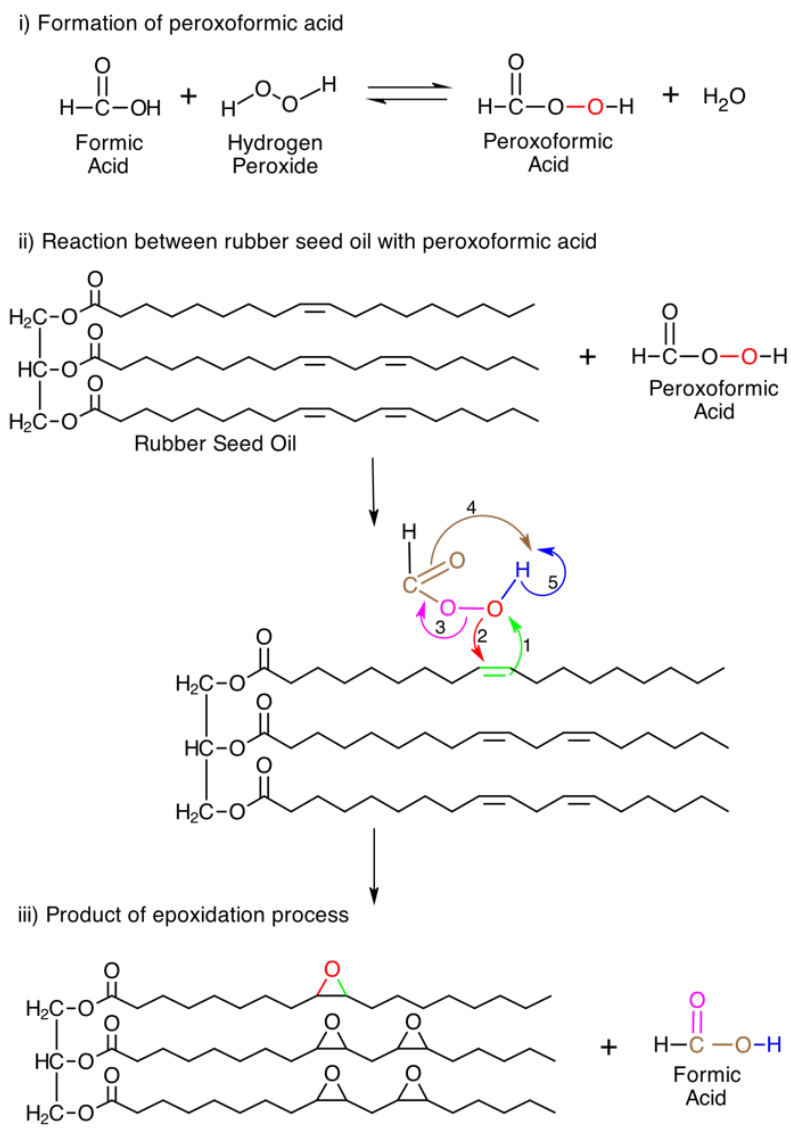

FIGURE 5. Epoxidation of RSO reaction mechanism

and the electron moves to oxygen (label in brown).

Following this, carbon dioxide will react with opened epoxide ring as illustrated in Figure 6(iii). Figure 7 depicted the formation of cyclic carbonate ring from reaction of carbon dioxide with opened epoxide ring. The extra pair of electrons (label in pink) in oxygen (label in brown) attack (label as 3) carbon (label in blue) as this carbon is partially positive charge. This breaks the bond 
(label as 4) between carbon-oxygen and the electrons move to the oxygen. This reaction resulting in the oxygen to be negative charge and a bond (label in pink) is formed. By taking advantage of Hofmann elimination reaction, the negative charge oxygen (label in cyan) will attack (label as 5) another carbon (label in red) of the opened ring which is partially positive charge due to being attached with bromine (label in green). Consequently, a bond is formed and yield a 5-membered cyclic carboxylate ring and bond of carbon-bromine (label as 6) to break.

i) Ring Opening of Epoxidised Rubber Seed Oil
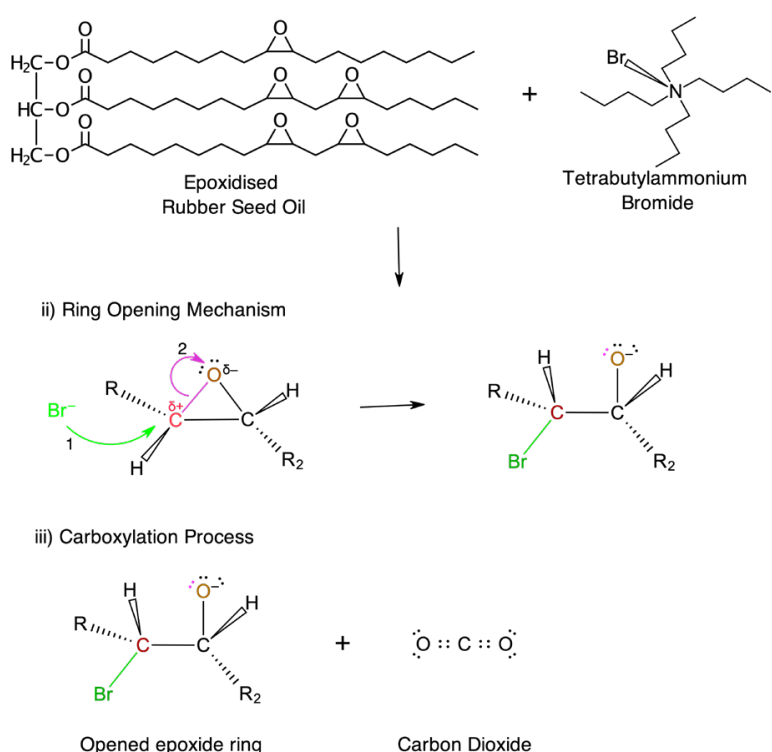

FIGURE 6. Carboxylation of RSO reaction mechanism - Part A

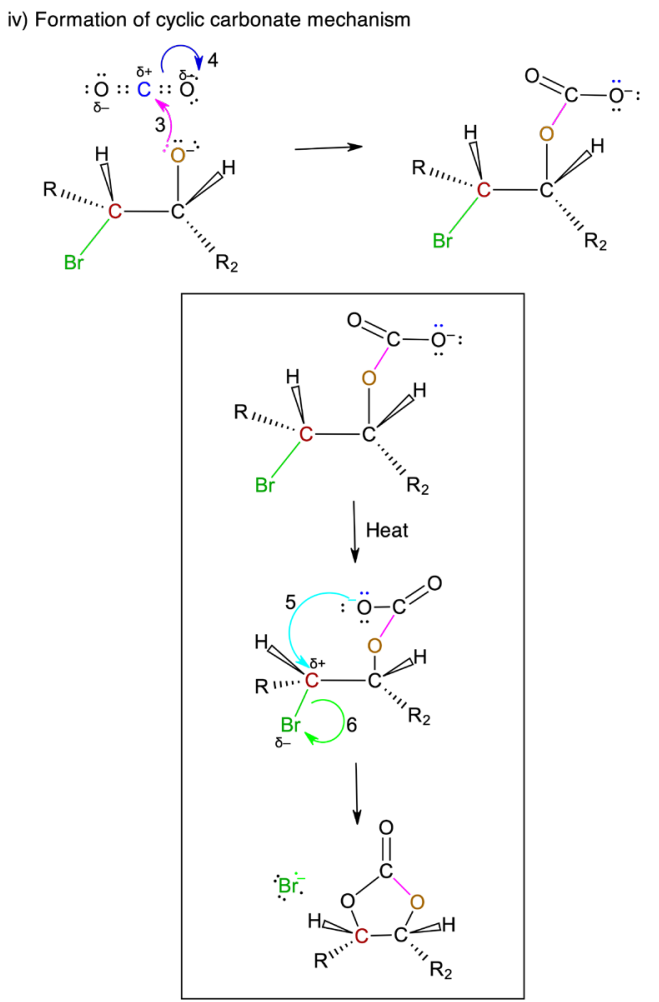

FIGURE 7. Carboxylation of RSO reaction mechanism - Part B 


\section{FOURIER TRANSFORM INFRARED SPECTROSCOPY}

Reaction conversion of RSO into carbonated RSO was monitored using infrared (IR) spectroscopy. Figure 8 depicted observation of spectral changes in IR spectra of RSO, epoxidised oil and carbonated oil as the conversion occurred. The emerging of peak at $822 \mathrm{~cm}^{-1}$ of epoxidised oil spectra represent the unsaturated group had been converted into epoxide. In carbonated oil spectra, additional peaks were seen to appear as the epoxide peak reduces in intensity area. Peak number $1804 \mathrm{~cm}^{-1}$ attributed to carbonyl group while $1045 \mathrm{~cm}^{-1}$ illustrate $\mathrm{C}-\mathrm{O}$ of cyclic carbonate, confirming conversion of epoxide group to cyclic carbonate. This is in line with finding from (Kathalewar et al. 2014). The peaks for methylene linkages, aromatic $\mathrm{C}-\mathrm{H}$ bonds, $\mathrm{C}-\mathrm{O}-\mathrm{C}$ ether bond were also observed in the FTIR spectrums as depicted in the Figure 8 .

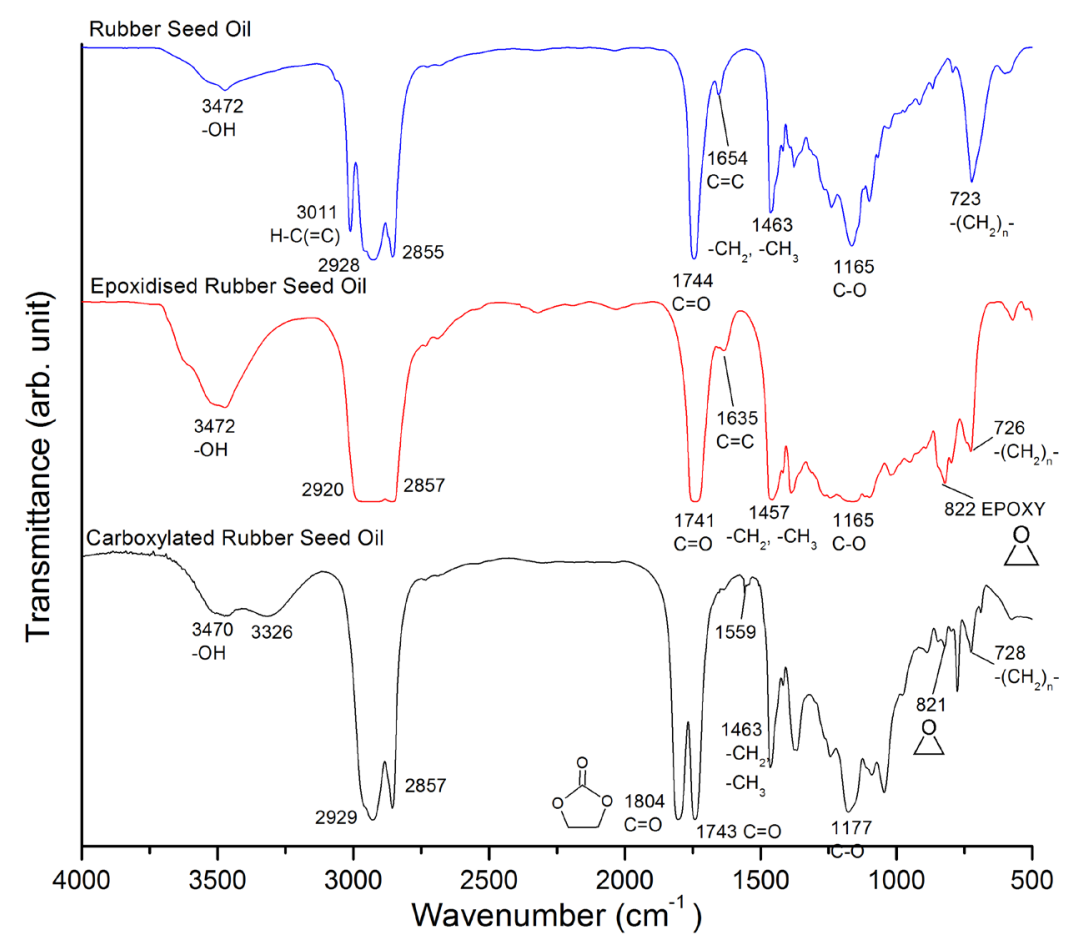

FIGURE 8. FTIR Spectroscopy of RSO, ERSO, and carboxylated oil

\section{${ }^{1} \mathrm{H}$ NUCLEAR MAGNETIC RESONANCE ('HNMR)} SPECTROSCOPY

As published in our previous studies (Raden Siti Amirah et al. 2013), ${ }^{1}$ HNMR spectroscopy result in Figures 9 and 10 supported the FTIR result on conversion of epoxide into cyclic carbonate. Peak corresponding to epoxide group of ERSO can be seen at $\delta 3.02$ (label as vii) in Figure 9. As this peak (label as vii) reduced in intensity in Figure 10, new peaks at signal $\delta 4.83$ (label as xiii) and $\delta 4.61$ (label as xii) emerged, which represented cyclic carbonate group (Doll \& Erhan 2005b). 

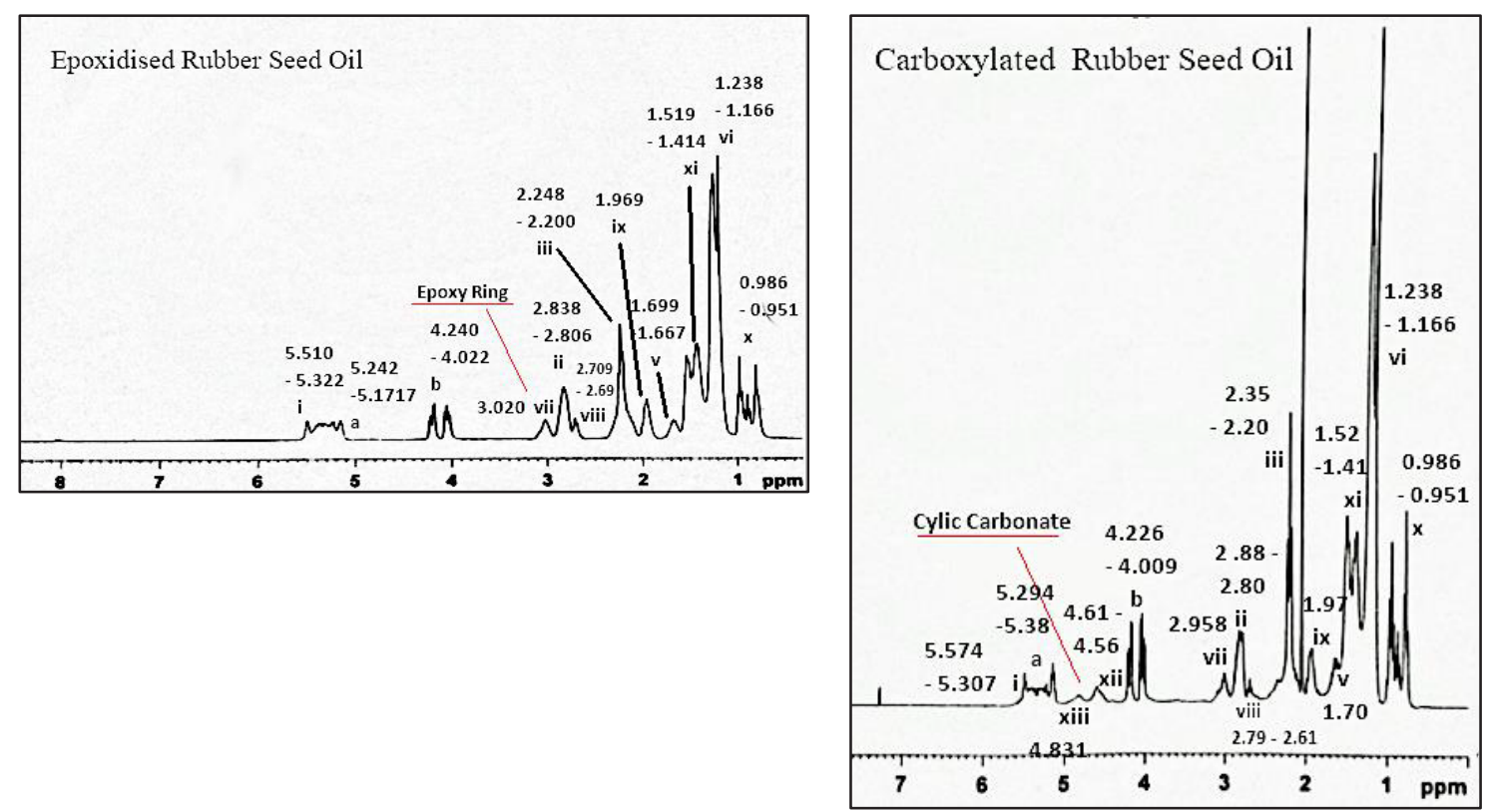

FIGURE 9. ${ }^{1}$ HNMR Spectroscopy of ERSO

FIGURE 10. 'HNMR Spectroscopy of carboxylated oil

\section{SYNTHESIS OF NON-ISOCYANATE POLYURETHANE}

Non-isocyanate polyurethane film produced was characterized for urethane linkage conversion via FTIR spectroscopy. Figure 11 displayed the conversion of cyclic carbonate into urethane linkage. Cyclic carbonate peak at wavenumber $1804 \mathrm{~cm}^{-1}$ had disappeared. This indicated cyclic carbonate group had reacted with amine from ethylene diamine to yield urethane linkage. The presence of amine can be observed at $3302 \mathrm{~cm}^{-1}$.

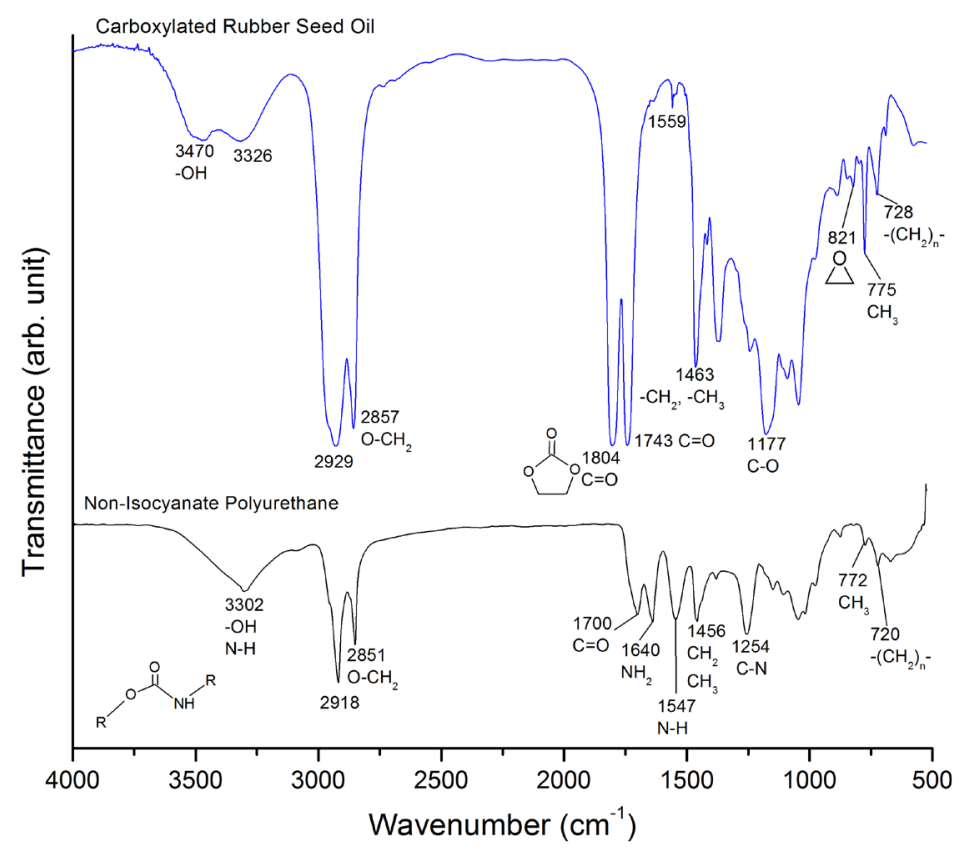

FIGURE 11. FTIR Spectroscopy comparison of carboxylated oil and non-isocyanate polyurethane film 


\section{CONCLUSION}

Rubber seed oil was epoxidised using peroxoformic acid formed in-situ. Epoxidised rubber seed oil was then purged with carbon dioxide and later reacted with a diamine to produced non-isocyanate polyurethane. The effect of temperature and ratio of hydrogen peroxide and formic acid during the epoxidation process was studied. 50, 60 and $70{ }^{\circ} \mathrm{C}$ (designated as T50, T60, and $\mathrm{T} 70$, respectively) were the temperature difference that being studied. T50 was the optimum temperature for the epoxidation reaction. It is found that the increase in the molar ratio of hydrogen peroxide, resulting in increasing of oxirane number whilst as the amount of formic acid increased, epoxide number produced was reduced.

\section{ACKNOWLEDGEMENTS}

Authors would like to thank Faculty of Applied Sciences, Universiti Teknologi MARA for their support in allowing the usage of equipment and laboratory. Authors would like to thank Lembaga Getah Malaysia for providing rubber seed oil for research purposes.

\section{REFERENCES}

Abdullah, B.M. \& Salimon, J. 2010. Epoxidation of vegetable oils and fatty acids: Catalyst, methods and advantages. Journal of Applied Sciences 10(15): 1545-1553.

ASTM D5554 - 95. 2011. Standard test method for determination of the iodine value of fats and oils. American Society for Testing and Materials (ASTM).

Boutin, M., Lesage, J., Ostiguy, C., Pauluhn, J. \& Bertrand, M.J. 2004. Identification of the isocyanates generated during the thermal degradation of a polyurethane car paint. Journal of Analytical and Applied Pyrolysis 71(2): 791-802.

Chiniwalla, P., Bai, Y., Elce, E., Shick, R., Christopher McDougall, W., Bidstrup Allen, S.A. \& Kohl, P.A. 2003. Crosslinking and decomposition reactions of epoxide functionalized polynorbornene. Part I. FTIR and thermogravimetric analysis. Journal of Applied Polymer Science 89(2): 568-577.

Corcuera, M.A., Rueda, L., Fernandez d'Arlas, B., Arbelaiz, A., Marieta, C., Mondragon, I. \& Eceiza, A. 2010. Microstructure and properties of polyurethanes derived from castor oil. Polymer Degradation and Stability 95(11): 2175-2184.

Datta, J. \& Włoch, M. 2016. Progress in non-isocyanate polyurethanes synthesized from cyclic carbonate intermediates and di- or polyamines in the context of structure -properties relationship and from an environmental point of view. Polymer Bulletin 73(5): 1459-1496.
Doll, K.M. \& Erhan, S.Z. 2005a. The improved synthesis of carbonated soybean oil using supercritical carbon dioxide at a reduced reaction time. Green Chemistry 7(12): 849854.

Doll, K.M. \& Erhan, S.Z. 2005b. Synthesis of carbonated fatty methyl esters using supercritical carbon dioxide. Journal of Agricultural and Food Chemistry 53(24): 9608-9614.

Durbetaki, A.J. 1958. Determination of oxirane oxygen in salts of epoxy acids and in the presence of amines. Analytical Chemistry 30(12): 2024-2025.

Harper, C.A. \& Petrie, E.M. 2003. Plastics Materials and Processes: A Concise Encyclopedia. Hoboken, New Jersey: John Wiley \& Sons, Inc.

Hong, L.K., Yusop, R.M., Salih, N. \& Salimon, J. 2015. Optimization of the in situ epoxidation of linoleic acid of Jatropha curcas oil with performic acid. The Malaysian Journal of Analytical Sciences 19(1): 144-154.

Huang, C.H., Lou, C.W., Chuang, Y.A., Liu, C.F., Yu, Z.C. \& Lin, J.H. 2015. Rigid/flexible polyurethane foam composite boards with addition of functional fillers: Acoustics evaluations. Sains Malaysiana 44(12): 1757-1763.

Ikwuagwu, O.E., Ononogbu, I.C. \& Njoku, O.U. 2000. Production of biodiesel using rubber [Hevea brasiliensis (Kunth. Muell.)] seed oil. Industrial Crops and Products 12(1): 57-62.

Karateev, A., Litvinov, D. \& Kalkamanova, O. 2014. "Nonisocyanate" polyhydroxy urethanes based on the raw material of a plant origin. Chemistry \& Chemical Technology 8(3): 329-338.

Kathalewar, M., Sabnis, A. \& D’Mello, D. 2014. Isocyanate free polyurethanes from new CNSL based bis-cyclic carbonate and its application in coatings. European Polymer Journal 57: 99-108.

Lu, Y. \& Larock, R.C. 2010. Soybean oil-based, aqueous cationic polyurethane dispersions: Synthesis and properties. Progress in Organic Coatings 69(1): 31-37.

Mohd Soberi, N.S., Rahman, R. \& Zainuddin, F. 2017. Effect of kenaf fiber on morphology and mechanical properties of rigid polyurethane foam composite. Materials Science Forum 888: 188-192.

Raden Siti Amirah, H., Ahmad Faiza, M. \& Samsuri, A. 2013. Synthesis and characterization of non-isocyanate polyurethane from epoxidized linoleic acid - a preliminary study. Advanced Materials Research 812: 73-79.

Rosato, D.V. 1993. Rosato's Plastics Encyclopedia and Dictionary. Hanser Gardner Publications.

Yadav, S., Zafar, F., Hasnat, A. \& Ahmad, S. 2009. Poly(urethane fatty amide) resin from linseed oil - a renewable resource. Progress in Organic Coatings 64(1): 27-32.

R.A. Raden Siti Amirah \& M.A. Faiza*

School of Industrial Technology

Universiti Teknologi MARA

40450 Shah Alam, Selangor Darul Ehsan

Malaysia 
A. Zuliahani

Faculty of Applied Sciences

Universiti Teknologi MARA, Perlis Branch

02600 Arau, Perlis Indera Kayangan

Malaysia
*Corresponding author; email: ahmadfaiza@uitm.edu.my

Received: 27 April 2020

Accepted: 18 December 2020 